\title{
Creative Thinking Training in Elementary School Fine Arts Teaching on the Background of Innovative Education
}

\author{
Hui Liu \\ College of Art and Communication, Bohai University, Jinzhou, 121013, China \\ 312587995@qq.com
}

Keywords: innovative education; elementary school fine arts teaching; creative thinking; training strategies

\begin{abstract}
The traditional teaching mode dominates the art classroom in primary school, and does not meet the requirements of quality education. Under the background of innovative education, new requirements are put forward for elementary school fine arts teaching. In view of the existing problems in elementary school fine arts teaching, guided by the theory of innovative education, this paper analyzes the composition of creative thinking training in elementary school fine arts teaching, and puts forward the creative thinking training strategies of primary school art teaching under the background of innovative education. The specific strategies are as follows: changing the teaching mode, stimulating the interest of art, cultivating the aesthetic ability, observing and discovering carefully; setting up reasonable doubt in teaching, opening the source of thinking; creating good atmosphere and drawing mind map; develop the power of imagination, release the natural personality; encourage students to stimulate creative thinking; encourage the exploration of differences, enhance students' confidence; make the integration of information technology and the development of art resources.
\end{abstract}

\section{Introduction}

Innovation education, according to the principle of innovation education and the law of education, to achieve a main target of educational theory and method by cultivating students' innovative consciousness, innovation thinking, innovation way and innovation ability, simultaneously pay attention to the students' knowledge and cultivate students' innovative spirit and practical ability. Fine arts education is an important part of quality education, and an important way to cultivate students' innovative spirit and practical ability. Art education has an important influence on people's thoughts, feelings, will, interests and hobbies, and plays an important role in the cultivation of all-round talents in the future. Innovation is the eternal theme of human society. The main idea of art education is to develop people's subjectivity, and the cultivation of innovative consciousness is the ultimate goal of the development of subjectivity[1]. In the comprehensive implementation of quality education today, in the art of teaching, the teacher's task is not only to cultivate artistic talents, intrinsic appeal more to tap the art, play the creativity of students, cultivate the spirit of innovation, the innovation consciousness and ability to effectively develop and improve, and strive to cultivate high-quality talents with a spirit of innovation.

"The standard of compulsory education art curriculum" clearly pointed out that modern society needs to give full play to each person's subjectivity and creativity, art curriculum should pay special attention to the cultivation of students' personality and innovation spirit, adopt various methods to help students learn to use the method of creative art, translated innovation into concrete results. Through the study on comprehensive learning and learning, guide students to explore and discover in the specific situation, to find the association between different knowledge, to develop the comprehensive practice ability, to solve the problems creatively. The art teaching content should be suitable for the psychological and physiological characteristics of the students, pay attention to the gradual and interesting, is conducive to the cultivation of students' image thinking ability, innovation spirit and practice ability. Primary school art teaching at present, most of the art teachers 
only pay attention to students' basic painting skills, and the development and cultivation of students should possess in the fine arts in the learning process of creative thinking and innovation ability has received little attention. In this paper, to cultivate students' divergent thinking, stimulate the students' interest and inspire students' imagination, cultivate students' ability of observation and encourage students to explore innovative, research on cultivating pupils' creative thinking ability.

\section{Innovative Education Theory}

Innovation education, is a teaching method to cultivate innovative talents using the scientific method based on modern advanced education theory, according to the principle of creative development.

(1) The target orientation of innovative education. It includes innovation spirit and innovation ability. The spirit of innovation is to have knowledge, information, skills and methods of the integrated use of existing, put forward new ideas and new methods, thinking ability, creative will, confidence, courage and wisdom. Innovation ability is the ability to continuously provide new ideas, new theories, new methods and new inventions in the field of technology and various practical activities.

(2) The core idea of innovative education [2]. Innovative education requires that students should be viewed with appreciation, so that each student's potential can be brought into full play. Educators believe that every student can be created, especially the creative potential of "backward students". Every student is a land that needs to be developed or reclaimed, and turns the potential of students into reality. Teachers should treat every student well in practice, and strive to develop the creative potential of every student.

(3) The implementation plan of innovative education. The implementation of innovative education is to start from the cultivation of innovative spirit, to improve the ability to innovate as the core, to promote the overall quality of students' independent construction and coordinated development. The implementation scheme of innovative education includes four aspects: guiding ideology, implementation goal, implementation principle and implementation way. Among them, the implementation goals include student goals, teacher goals, evaluation objectives and management objectives. The way of implementation should be utilized in a variety of ways according to the actual situation and play a comprehensive role.

\section{Composition on Creative Thinking Training in Elementary School Fine Arts Teaching}

In the elementary school fine arts teaching, the teaching effect is the most direct manifestation of the quality of teaching. Only innovative thinking ability can be improved, students can give full play to the imagination art in the process of learning. Only the bold and innovative students in the painting process, in order to improve the effect of elementary school fine arts teaching. Elementary school fine arts teaching creative thinking training consists of three aspects:

(1) Cultivate innovative thinking. Creative thinking is a creative way to invent or discover a new way of dealing with certain things or expressing some things. It is creative thinking in the aspects of thinking method, thinking form and thinking process. The cultivation of logical thinking in elementary school fine arts teaching is also an important work. Innovative thinking can be achieved through the integration of logical thinking. Logical thinking and artistic thinking interact to promote the cultivation of innovative thinking.

(2) Cultivate divergent thinking. Divergent thinking analyzes and understands problems from the perspective of differentiation, and draws new ideas and new ways of thinking. It is an effective way to improve creative thinking. Divergent thinking has the characteristics of breaking the old thinking and not being fettered by the existing knowledge and ideas. Children's thinking is the psychological journey of their discovery and exploration, and art education helps to develop divergent thinking. By enjoying the pictures and enjoying the beautiful scenery, we can enjoy the beauty.

(3) Cultivating imaginative thinking. Imaginative thinking is the embodiment of imaginal thinking. It is the most important form of human brain processing with the aid of imagery, and it is 
an important thinking form of human innovation and its activities. An important feature of modern art education is imagination thinking and innovative thinking, the main teaching content is to cultivate modeling performance, design and application of comprehensive exploration ability, which is the most effective way to cultivate the imagination and creativity.

\section{Creative Thinking Training Strategies in Elementary School Fine Arts Teaching on the Background of Innovative Education}

According to the situation and development strategy refers to the development course of action and struggle, is a set of scheme can achieve the target. In this paper, the theory of innovation education and creative thinking in art education based on the idea, in view of the existing elementary school fine arts teaching, integrated elementary school fine arts teaching creative thinking training, the proposed strategy are as follows:

(1) The change of teaching mode, to stimulate interest in art. The art teaching mode in art teaching thought and theory, set up a relatively stable teaching activity framework and procedure. As a structural framework, it highlights the teaching model, grasps the whole of the teaching activities and the internal relations and functions between the elements. As an activity program, it highlights the orderliness and operability of the teaching model. In the art of teaching, teaching method, demonstration method, discussion method and experimental method are the specific teaching methods, the different teaching methods according to the procedure and the proportion of the combination of teaching strategies and teaching methods will be different according to the procedure and the proportion of specific composition teaching strategies form the teaching mode. At the same time, we should pay attention to stimulate students' interest, the new art curriculum standards pointed out that "interest is one of the basic driving force of learning art", through interest to mobilize the enthusiasm and initiative of students, pioneering imagination, stimulate innovation ability, better achieve the goal of art teaching [3].

(2) The cultivation of aesthetic ability, carefully observed. The aesthetic ability, stimulate students' interest in art hobbies, to explore students' creative thinking. The aesthetic can not only edify sentiment, perfect personality, to promote the harmonious development of body and mind, but also to stimulate learning motivation and promote the all-round development of morality, intelligence, body, beauty, to the spiritual sublimation, promote intellectual development, develop thinking and innovation ability training. In the art teaching, teachers should guide students to appreciate the beauty of nature, taste the beauty of life, appreciate the beauty of art, so that students can get inspiration from aesthetic, and show their thoughts in life. The emotion of the students can be expressed and expressed naturally, and the purpose of aesthetic education is achieved. Teachers should guide students to learn to observe, observe attentively, and boldly innovate on the basis of grasping the overall characteristics of the object of painting. Life is the source of art, guiding students to observe carefully, to grasp the important characteristics of things, and to use the brush to retain the beauty of life.

(3) Teaching reasonable doubt, open the source of thinking. Creation begins with problems, problems promote exploration. Problem awareness and problem ability are the basis of creativity and innovation. There are problems, there will be thinking, with thinking, there are ways to solve the problem. The new curriculum reform advocates creating situations, setting reasonable doubts, creating an effective environment for students to think flexibly, letting students enter the best learning state as soon as possible, and acquiring the most effective knowledge in the shortest possible time [4]. Set questions for students, let students in the exploration of thinking to verify questions, refining knowledge, sublimation of the concept. Imagination is the source of creative thinking, and Einstein says, "all creative work begins with creative imagination." Imagination permeates every aspect of life and learning, every student should have the psychological quality. The teacher through classroom assignments, painting, or painting to take the theme, is to arouse students' awareness of subjective thinking ability, let the students take the classroom tasks into conscious thought consciousness, training students' imagination.

(4) Creating good atmosphere and drawing mind map. In the art class teaching, teachers should 
strive to create a relaxed and harmonious classroom atmosphere, so that students feel happy, courage to express their views [5]. When painting demonstration, do not emphasize to let the students write with a teacher, requiring students to have their own innovation. Only the maximum good teaching atmosphere to arouse the enthusiasm of the students, only to mobilize the enthusiasm of students to cultivate students' artistic accomplishment fundamentally. Mind map can simulate the whole thinking process of human beings and show people's thinking state through a visible form. It is an important tool to cultivate students' creative thinking. Mind has more appeal than text, can effectively improve the students' creative thinking, enhance students' spatial memory. In art class, teachers can draw some graphics, creative thinking of students in regular training, improving students' thinking and ability of information processing, reduce the traditional oral preaching theory teaching mode.

(5) Give full play to imaginative power and release natural individuality. Primary school students like fantasy, unlike adults are bound by inherent thinking methods and thinking habits. Teachers should encourage students to imagine, and use vivid and passionate language to stimulate their free imagination [6,7]. Instead of using fixed pictures and styles to limit creation, they create situations full of fantasy and bring them into the works. Through a large number of preparing teachers before class, students can choose the form of painting and painting tools according to their own favorite. This creative space is large, creative thinking played more creative freedom, out of the picture is more abundant. In the painting of liberty, every student is out of the ordinary way of artistic expression, encourage them to try different creative forms, often inspire new ideas, to create unique works of art. Teachers should fully guide students, play their unique imagination, the greatest extent to broaden the students' thinking, so that students release natural personality in the art creation.

(6) Encourage students to stimulate creative thinking. Art teaching, to stimulate students' creative thinking, is to activate the students' divergent thinking, let the students according to the factors of art imagination, the formation of new artistic image. Through the excavation of students' inherent potential, improve the level of intelligence, training students' observation, analysis, integration and resolution and other thinking ability. Art works, including painting, sculpture, paper cutting and woodcut and other forms of expression, for primary school students, not to learn these expression techniques, but to promote innovation in the production of art works [8]. To encourage students to start smart thinking, with abundant materials, unique artistic technique, shows the character of creative thinking. The art teaching has its own characteristics, in the respect of teaching law at the same time, the development of students' thinking, advocating individuality creation, to stimulate students' creativity. The art teaching is a very practical course, let the students develop in practice imagination, create works of art in the vision, it has a positive effect on enhancing the overall quality of students.

(7) Encourage the exploration of differences, enhance students' confidence. Knowledge is a necessary condition for the formation of creative thinking ability, but knowledge is not equal to the ability of creative thinking, and the divergent thinking is one of the most important form of thinking. Divergent thinking is a problem from a different direction, even in the opposite direction, thinking process and methods to explore different answers, is the most important method of creative thinking. Creativity comes from the basic cognitive process, through the cognitive process of knowledge to cultivate students' innovative ability. Self-confidence is a valuable psychological quality. Art education plays a very important role in promoting the growth and development of young people and cultivating self-confidence. The direct purpose of art education is looking for opportunities, the use of a variety of ways of training people's physical and mental and sensory organs, promote observation, memory, thinking, imagination, creativity and moral emotion and other aspects of the upgrade. Constantly improve the quality of art classroom teaching, play the role of art education, and promote the overall development of students.

(8) Integrating information technology and expanding art resources. The wide application of information technology has improved the ability of practical teaching and innovation, and improved the teaching level of multiple intelligences. The introduction of information technology into the classroom, assisted teaching, enhance the charm of knowledge, the realization of the abstract 
problem specific, so that students can play the subjective initiative, thinking more flexible [9]. It is mainly used in two aspects: first, making courseware with computer, creating various forms of classroom; second, using network resources to cultivate students' creative thinking ability. The development of information technology provides a new way for the development of art teaching resources. The development and utilization of art teaching resources is a supplement to teaching materials. It broadens the scope of art teaching, promotes the development of fine arts teaching, and promotes the all-round development of students. Campus environmental resources and campus cultural resources are the main factors for the development and utilization of art teaching resources. The development of art teaching resources should consider the existing resources, combine with the existing resources, and improve the efficiency of utilization. The development of art teaching resources should be combined with the unique culture of the campus, facing all the students, encouraging students to participate in, and cultivating students' ability to discover beauty and create beauty in life.

\section{Acknowledgement}

This work is supported by 2017 annual "Thirteenth Five Year" Education and Science Planning Project in Liaoning Province (JG17CB336): Creative thinking training in elementary school fine arts teaching on the background of innovative education.

\section{References}

[1] C. B. Sun, "Exploration of art education practice teaching and innovative consciousness training program," Contemporary Education Research and Teaching Practice, vol. 3, no. 1, pp. 62-65, 2015.

[2] Baidu Knows, "The core idea of innovative education," https://zhidao.baidu.com/question/1757901047264288388.html, 2017-7-10.

[3] K. Lu, "Stimulate creative thinking, Improve artistic quality," Primary School Times, vol. 6, no. 20, pp. 8-8, 2014.

[4] D. X. Zhang, "Cultivation of creative thinking in primary school art teaching," Education Teaching Forum, vol. 5, no. 23, pp. 35-36, 2013.

[5] C. Luo, "How to create a good atmosphere for art teaching," http://www.docin.com/p-262078313.html, 2017-7-11.

[6] Baidu Wenku, "Talking about the imaginative power in art class," https://wenku.baidu.com/view/6cc6876e4b73f242326c5f04.html, 2017-7-10.

[7] Q. R. Li, "How to cultivate students' creative thinking in primary school art teaching," Learning Weekly, vol. 13, no. 13, pp. 209-210, 2017.

[8] J. Zheng, Q. Zhang, "Heuristic Teaching and Innovation in Children's Art Education," Journal of aesthetic education, vol. 7, no. 1, pp. 97-100, 2016.

[9] J. J. Li, "How to develop creative education in primary school art teaching," Education for Chinese After-school(Theory), vol. 8, no. 17, pp. 154-154, 2014. 